\title{
Enhancing Relationship Quality: The Case of Franchises
}

\author{
Shueh-Chin Ting \\ Department of Education, National University of Tainan, Taiwan \\ E-mail: tingsc@ms49.hinet.net
}

Received: June 1, 2014

Accepted: July 30, 2014

Published: July 30, 2014

doi:10.5296/jmr.v6i3.5981

URL: http://dx.doi.org/10.5296/jmr.v6i3.5981

\begin{abstract}
What circumstances enhance franchise relationship quality is not well understood. We help to fill this research gap by developing and testing a model of the sources of relationship quality using constructs from the transactions cost literature, including idiosyncratic investment and interdependence. A survey was conducted successfully to 550 franchise owners or managers of Taiwanese small and medium enterprises. We find that idiosyncratic investment directly enhances trust and indirectly reinforces trust via interdependence. Franchisees' idiosyncratic investment cannot directly influence opportunistic behavior but indirectly influence it via trust or interdependence. Moreover, franchisees with lower opportunistic behavior and higher trust have higher commitment.
\end{abstract}

Keywords: Franchise, Relationship context, Relationship quality, Relationship marketing 


\section{Introduction}

Many problems affect franchising performance, including relationship quality (Dertouzos, Lester, and Solow, 1989). However, franchisers often neglect relationship quality, feeling that franchising contracts bind franchisees to the relationship and franchisee feelings are unimportant.

Previous studies of relationship quality have explored ordinary channel stores, but studies on chains are lacking. Chains are hierarchically governed, while ordinary stores are market governed. Franchisees are vertically integrated and regulated by franchising contracts. Thus, it is unclear whether the research findings on ordinary stores are applicable to chains. Therefore, this study uses franchises to explore relationship quality.

Enhancing relationship quality between franchisers and franchisees is an important strategic issue. However, the types of relationship context that strengthen the relationship quality between franchisers and franchisees remain unclear. Although Brown, Dev, and Lee (2000) examined the influence of idiosyncratic investment on opportunistic behavior within the hotel franchise industry, only direct influence was examined. This study explores the question of which relationship contexts reinforce franchiser-franchisee relationship quality and how they do so. We include two relationship context variables: idiosyncratic investment and interdependence to explore their influences on relationship quality (including opportunistic behavior, trust and commitment).

This study may help franchisers strengthen their relationship quality with franchisees by identifying the key source of relationship quality. The results also clarify the important roles of idiosyncratic investment and interdependence in franchising relationships.

\section{Literature and Hypotheses}

\subsection{Franchising}

Franchising is a form of organizational cooperation, in which franchisers empower franchisees to do business for a particular period and in a specific location under defined conditions. Franchisers obtain royalties or receive charges in return. The firms that empower others are called franchisers, and those that receive the power are called franchisees. The power refers to the franchise (Elango and Fried, 1997).

Franchises represent a group of firms in the same industry that shift from competition to cooperation. They represent upstream-downstream cooperation. For a franchiser, franchises have many benefits. For instance, they allow the rapid deployment of a large sales system with less investment and lower risk to increase market share and reputation. In addition, franchise scale economies create lower purchase and promotion costs, increasing market competitiveness. Franchise stores are the franchisees' own businesses, meaning that franchisees work to promote them. Franchisers thus acquire dedicated partners. Franchisees also benefit. With the franchisers' guidance, franchisees can launch their stores immediately, learn business and management skills, and reduce the risk of failure. They can use the reputation and knowledge of the franchisers to increase sales. In addition, franchisees can 
obtain marketing effects (such as national advertising) that cannot be acquired by independent stores.

\subsection{Idiosyncratic investment}

Idiosyncratic investment is an investment in a specific relationship and it is difficult to use such an investment for another relationship. Therefore, unless cooperation in the relationship continues, an idiosyncratic investment will become valueless (Anderson and Weitz, 1992). Several scholars have contended that after a substantial investment in the physical or human assets of a given supplier, a retailer will encounter switching costs if he switches to another supplier (Erramilli and Rao, 1993; Heide, 1994).

Idiosyncratic investment includes intangible and tangible assets. Tangible assets include facilities and equipment purchased by franchisees to meet the franchisers' requirements. Intangible assets can be the accumulated professional knowledge and work relationships of the franchise operations after the long-term investment of time and effort (Goodman and Dion, 2001). Experience-based intangible assets are necessary for accomplishing product transactions. However, these intangible assets are sometimes exclusive, special assets that cannot be freely transferred.

\subsection{Interdependence}

According to research on organizations, when employees and leaders are conscious of being "in the same boat" or perceive that they are interdependent, positive behavior will result. Interdependence usually generates feelings of social attraction, empathy, and trust. To encourage group members to behave in ways beneficial to the group, merely treating them as part of the group is insufficient. Their consciousness of interdependence is an important element (Fairfield and Wagner, 2004).

Organizational members must work together to make sales. In studies on sales channels, interdependence is seen as an important concept (Kumar, Scheer, and Steenkamp, 1995b). Smith and Barclay (1999) explained interdependence as when two cooperating parties need the relationship, contribute their techniques, resources and value to the relationship, and perceive the exclusiveness of the relationship.

\subsection{Opportunistic behavior}

Opportunistic behavior refers to one party taking action for its own benefit without concern for any possible harm to the other (Williamson, 1975). Opportunistic behavior is usually based on deceit and conflicting goals (Larson, 1992; Tjosvold and Weicker, 1993). Williamson (1985) defined opportunistic behavior as the pursuit of maximum benefits using deceit. Such behavior generally violates explicit or implicit agreements. However, opportunistic behavior is assumed to be a basic principle in organizational economics (Ting, Chen, and Bartholomew, 2007).

\subsection{Trust}

The construction of a franchise system with competitive advantages and harmonious franchising relationships is important. Trust critically influences the positive interactions of an 
organization and plays a significant role in franchising operations and management (Morgan and Hunt, 1994).

Tan and Tan (2000) defined organizational trust as employees' perception based on their overall evaluation of the reliability of the organization. When employees trust organizations, they believe that organizational actions will benefit them or, at least, will not hurt them. According to Shockley-Zalabak, Ellis, and Winograd (2000), organizational trust is an individual's positive expectation regarding organizational members' intentions and behaviors. Garbarino and Johnson (1999) defined customers' trust in an organization as confidence in the organization's products and services. In this study, we define franchisee trust in franchisers as franchisees having confidence in the franchisers and believing that the franchisers will consider franchisee benefits when making decisions.

\subsection{Commitment}

Since the publication of Whyte's (1956) The Organization Man, organizational commitment has been variously defined and discussed. Porter, Steers, Mowday, and Boulian (1974) suggested that organizational commitment means individuals' identification with and involvement in a specific organization. Bowen and Shoemaker (1998) defined commitment as an individual's believing that continuing a relationship is extremely important to them, hoping to maintain the relationship, and being willing to make short-term sacrifices for long-term benefits. Based on Gruen, Summers, and Acito (2000), commitment can be treated as the members' psychological attachment to the organization.

Commitment is intent to maintain the relationship due to the long-term benefits, even in the event of a loss of short-term profits (Dwyer, Schurr, and Oh, 1987). In cooperation, commitment is an important base for the development of beneficial social norms (MacNeil, 1980) as well as the relationship outcome expected by the two parties. Porter, Steers, Mowday, and Boulian (1974) contend that members with a high degree of organizational commitment (1) strongly believe in and accept organizational goals and values; (2) have the intention to contribute more to the organization; and (3) desire to continue being part of the organization. All of these benefits incurred by commitment are importment to franchises, so we apply this implication of commitment to franchises, and use it to indicate one of relationship quality.

\subsection{The effect of idiosyncratic investment on interdependence}

Idiosyncratic investment is an investment that cannot be switched to other relationships. When franchisees have a large idiosyncratic investment in franchisers, switching costs (Heide and John, 1988) and relationship termination costs (Morgan and Hunt, 1994) increase. Termination of their cooperation could then result in serious loss. Because only the continuity of the relationship maintains the value of the idiosyncratic investment, franchisees are forced to depend on franchisers. Thus, there is a positive relationship between franchisees' idiosyncratic investment and their dependence on franchisers (Joshi and Stump, 1999; Palmatier, Dant, and Grewal, 2007).

Idiosyncratic investment in cooperation can create cooperative performance by which franchisee dependence is produced. For instance, after franchisees purchase and use the order 
system asked by the franchisers, performance will be promoted. To get the performance, the franchisees depend on their franchisers.

Franchisee idiosyncratic investment not only increases dependence on the franchisers but also increases franchiser dependence on franchisees. Franchisee idiosyncratic investments improve franchising performance and benefit franchisers. In addition, idiosyncratic investments in cooperation are concrete signals of franchisee intention to cooperate with franchisers. Sensing this, franchisers value their franchisees and may strengthen their relationship. If franchisers want to switch partners, they incur search costs and sacrifice the original franchising relationship. Idiosyncratic investments thus make franchisers more likely to depend on their original partners (Palmatier, Dant, and Grewal, 2007), increasing interdependence. We thus hypothesize the following:

\section{H1: Franchisees' idiosyncratic investment positively influences interdependence between franchisees and franchisers.}

\subsection{Effect of idiosyncratic investment on opportunistic behavior}

If franchisees do not intend to continue the relationship with the franchiser, they will reduce their investment in proprietary assets to cut their losses. Hence, when franchisees intend to invest in proprietary assets, it means they are willing to continue their franchising cooperation (Anderson and Weitz, 1992). Thus, franchisee investment in proprietary assets is a significant signal indicating the continuity of their cooperation. Investments in proprietary assets are tangible, specific, and have the effect of a guarantee of continued cooperation. Further, when franchisees invest in proprietary assets, their intention to continue cooperating with franchisers will increase. They will be less likely to adopt opportunistic behavior.

Because idiosyncratic assets are non-redeployable, switching partners will render the assets valueless. When franchisees invest in higher proprietary assets, the switching costs will increase if they terminate their current cooperation (Anderson and Weitz, 1992). If franchisees should terminate the original channel relationship due to opportunistic behavior, they will lose their investments in proprietary assets. Out of cost concerns, given high proprietary assets, franchisees will be less likely to adopt opportunistic behavior. Therefore, franchisees' idiosyncratic investments will inhibit their opportunistic behavior (Lui and Ngo, 2005).

Williamson (1985) suggested that proprietary assets can modify firms' selfish motives and stabilize cooperation. Through idiosyncratic investments, channel members create motives for cooperation. Investments in proprietary assets will lower the likelihood of searches for new cooperative relationships and will increase concern for the overall long-term benefits of the channel relationship.

Exploring proprietary product sales, Edison, Hunt, and Madhavaram (2007) suggested that the techniques and knowledge necessary to sell proprietary products are valueless in other fields and cannot be transferred. To obtain the requisite skills, the salespersons' learning (idiosyncratic investment) becomes an obstacle to salesperson turnover. When salespersons lose more by giving up their current job, they have no choice but to maintain the relationship. Opportunistic behavior is thus restrained. 
If franchisers can enhance franchisee investment in proprietary assets, they will create a level of cooperation that is difficult to replace. This cooperation prevents other franchisers from intervening and increases franchiser control over franchisees, restraining their opportunistic behavior. We thus hypothesize the following:

\section{H2: Franchisees' idiosyncratic investment negatively influences franchisees' opportunistic behavior.}

\subsection{Effect of idiosyncratic investment on trust}

Using relational exchange theory, Lui, Wong, and Liu (2009) investigated the procurement relationships between trading firms in Hong Kong and suppliers in China and found that asset specificity can increase trust among partners, leading to better cooperative behavior and partnership performance. Their findings further demonstrate that the relationship between asset specificity and trust (based on relational exchange theory) is closer than that between asset specificity and opportunism (as argued by transaction cost economics). Skarmeas and Robson (2008), investigating international channels, found that asset specificity is one of the antecedents of relationship quality. Hence, when franchisees have higher levels of idiosyncratic investment, it help franchisers and franchisees trust each other. Thus,

\section{H3: Franchisees' idiosyncratic investment positively influences franchisees' trust.}

\subsection{Effect of interdependence on opportunistic behavior}

When interdependence between franchisees and franchisers is high, they can acquire valuable contributions from each other. Further, when interdependence is high, the two parties will face stronger obstacles to leaving the relationship. Thus, they will be strongly motivated to maintain and strengthen the relationship (Kumar, Scheer, and Steenkamp, 1995b) and will avoid opportunistic behavior.

Sarkar, Aulakh, and Cavusgil (1998) studied resource-based interdependence and demonstrated that when interdependence caused by resources is higher, relational bonding will be higher. They suggested that the resource value that results in partnership will influence the perception of interdependence. When two parties need resources from each other, they cherish cooperation and refrain from opportunistic behavior.

Social exchange theory contends that in a relationship of asymmetric dependence, the party with more power will influence or control the other. Though superficially obedient, the inferior party will protect its interests (Lui and Ngo, 2005). With interdependence, power is balanced, fostering an equal exchange relationship without negative feelings in which the two parties can purse mutual long-term benefits. Thus,

\section{H4: Interdependence between franchisees and franchisers negatively influences franchisees’ opportunistic behavior.}

\subsection{Effect of interdependence on trust}

Both bilateral deterrence theory (Bacharach and Lawler, 1981) and social exchange theory suggest that higher interdependence will result in lower conflict and greater cooperation and 
trust (Kumar, Scheer, and Steenkamp, 1995b). However, if only one party depends on the other, the dependent party may question the other's intentions and take action to avoid harm. This imbalance may create distrust (Smith and Barclay, 1999). When the two parties perceive dependence, they are less likely to adopt opportunistic behavior, thereby fostering trust (Buchanan, 1992; Smith and Barclay, 1999). Therefore, interdependence is an important basis for the development of trust in a partnership (Kumar, Scheer, and Steenkamp, 1995b; Smith and Barclay, 1999). Thus,

\section{H5: Interdependence between franchisees and franchisers positively influences franchisees' trust.}

\subsection{Effect of trust on opportunistic behavior}

Franchisees' trust means that the franchisees have confidence in the franchisers and believe that they can accomplish future tasks with the franchisers. In trust-based franchising relationships, the franchisees positively evaluate franchiser actions. For instance, they tend to believe that franchisers will refrain from opportunistic behavior, even if they have the opportunity (Andaleeb, 1992; Moore, 1998). Thus, if franchisees predict that franchisers will not be opportunistic, franchisees will also avoid their own opportunistic behavior.

Ramaswami and Singh (2003) studied salespersons and suggested that some employees engage in opportunistic behavior. However, when salespersons trust their supervisors, they will be less likely to adopt opportunistic behavior. When two parties trust each other, they will be willing to share ideas and widely exchange information, discuss goals, and solve problems (Moorman, Zaltman, and Deshpande, 1992). Interpersonal trust guarantees the reduction of opportunistic behavior, because both parties believe that they will obtain fair returns through common efforts (Jap, 1999). Thus, interpersonal trust significantly influences the formation of collaborative organizational relationships (Ring and Van de Ven, 1992, 1994).

Kale, Singh, and Perlmutter (2000) applied the concept of relational capital to alliances. According to their research, alliance members' trust, respect, and friendliness toward each other represent important relational capital that can result in closer interaction. In addition, relational capital helps alliance members learn know-how and capabilities in the alliance relationship. It also helps to reduce opportunistic behavior. Thus,

\section{H6: Franchisees' trust negatively influences franchisees' opportunistic behavior.}

\subsection{Effect of opportunistic behavior on commitment}

Opportunistic behavior means that one party in the contract acquires selfish benefits through deceitful measures, without considering whether the behavior will hurt the other (Williamson, 1975). Opportunistic behavior is premeditated instead of unintentional and often harms the interests of others in the franchise system (Larson, 1992; Tjosvold and Weicker, 1993). Opportunistic behavior may cause conflicts between franchisees and franchisers. Because such behavior harms cooperation, it is not compatible with long-term partnerships (Gundlach, Achrol, and Mentzer, 1995; Joshi and Stump, 1999). In addition, opportunistic behavior pursues short-term benefits, whereas commitment sacrifices short-term benefits for long-term 


\section{Macrothink}

interests. Therefore, franchisees' opportunistic behavior is negatively related to commitment. Thus,

\section{H7: Franchisees' opportunistic behavior negatively influences franchisees' commitment.}

\subsection{Effect of trust on commitment}

Commitment includes potential harm and sacrifice. Franchisees will not easily commit to franchisers unless they trust them. Thus, trust is an antecedent of commitment (Garbarino and Johnson, 1999).

Using the general reciprocity principle, social exchange theory explains the causal relationship between trust and commitment. The theory suggests that trust is two-way. When people perceive that they are not trusted by others, they will become defensive and a reciprocal distrust will ensue. Transactions then become direct and short-term. Eventually, due to the mutual distrust, the degree of commitment in the relationship wanes (McDonald, 1981).

Trust is a value for a partnership (Arrow, 1974) that benefits both parties (Barber, 1983). First, in partnerships with trust, organizations will be willing to take risks, because they need not worry about their partners' opportunistic behavior (Morgan and Hunt, 1994). Second, in partnerships with trust, neither party needs to invest in monitoring the other nor are strict contracts necessary, which lowers or eliminates transaction costs (Andaleeb, 1996). Because trust can bring many benefits, two parties that trust each other will have a greater intention to continue the cooperation, and the degree of commitment will be higher. Organizational management research also indicates that trust in supervisors can increase subordinates' perception of the value of the relationship, which will increase commitment (Ramaswami and Singh, 2003). Based on the foregoing, we hypothesize the following:

\section{H8: Franchisees' trust positively influences franchisees' commitment.}

\section{Research Framework}

Based on the theoretical and empirical literature, we developed a research framework (Figure 1). Causal relationships among the variables are shown as arrows. 


\section{Macrothink}

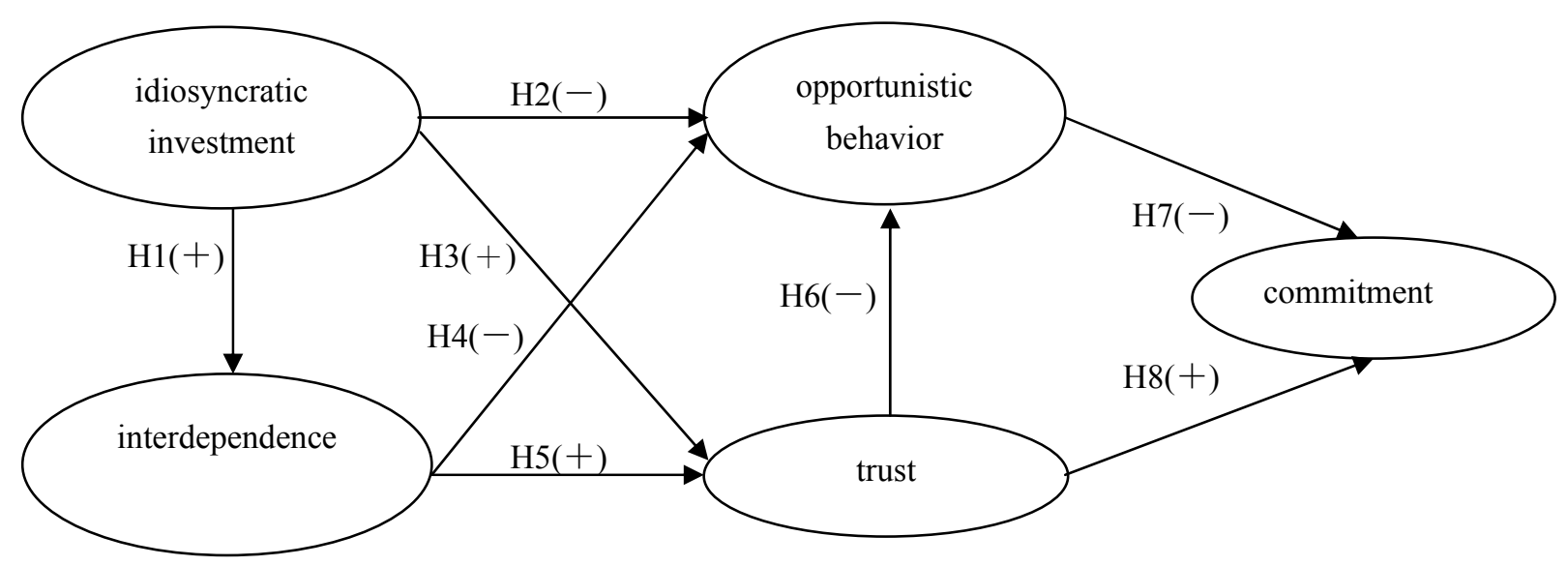

Figure 1. Research framework.

\section{Method}

\subsection{Measurement}

The survey instrument in this study is based on related scales in research on channels and on actual franchise systems in Taiwan. The wording of items has been revised. Based on Churchill (1979), this study designed the questionnaire using multiple indexes. There are five constructs, including two constructs for relationship context, idiosyncratic investment and interdependence, and three constructs for relationship quality, opportunistic behavior, trust and commitment. All measurements are based on a 7-point Likert-type scale, with scores ranging from strongly disagree (1 point) to strongly agree ( 7 points). Higher scores indicate that participant perceptions of the construct are higher. The following section describes the operational definitions, sources of scales, and construct items. The items are shown in Table 1.

\subsubsection{Idiosyncratic investment}

In this study, idiosyncratic investment refers to the franchisees' exclusive investment in the franchising relationship, which cannot be easily transferred to other partnerships. We drew on Anderson and Weitz (1992) to create the idiosyncratic investment measure. This measure describes the degree to which franchisees invest in training, facilities, and building a consistent customer image for the franchise.

\subsubsection{Interdependence}

In this study, interdependence refers to the reliance of franchisees and franchisers on each other to obtain positive operational results that cannot be easily acquired from other sources. As to the measurement of dependence, this study focused on replaceability. Many studies have measured dependence using replaceability (Buchanan, 1992; Frazier and Rody, 1991; Heide, 1994; Kumar, Scheer, and Steenkamp, 1995b). The scale of replaceability used in our survey tool was developed by Kumar, Scheer, and Steenkamp (1995b). It includes the ease of locating new partners, switching costs, and collaborative performance. The measurement of interdependence includes two parts: franchisees' dependence on franchisers and franchisers' 
dependence on franchisees. The items on the scale were evaluated by franchise owners or managers of franchise stores. The mean of the dependence of the two parties is the score of interdependence in this study.

\subsubsection{Opportunistic behavior}

Opportunistic behavior in this study refers to the franchisees' acquisition of benefits by deceitful measures when cooperating with the franchisers. In this study, the measurement of opportunistic behavior is drawn from the scale of opportunistic behavior developed by Provan and Skinner (1989).

\subsubsection{Trust}

Trust in this study refers to the franchisees' belief that the franchisers are honest and kind. Franchisers' honesty means that they will keep promises and fulfill their role duties. Franchisers' kindness means that they will care about, help and support the franchisees. In addition, franchisers will not injure the franchisees through their actions. The measurement of trust is based on items on trust developed by Kumar, Scheer, and Steenkamp (1995a, 1995b).

\subsubsection{Commitment}

Commitment in this study refers to affective commitment. Specifically, because franchisees interact with franchisers, they have established affection and intend to maintain a long-term relationship. The measurement of commitment was drawn from the scale of affective commitment developed by Meyer, Allen, and Smith (1993).

\subsection{Questionnaire development}

After completing a draft of the questionnaire, we revised it in two steps. First, it underwent expert examination. Two marketing researchers and two franchisees examined the items with regards to the appropriateness of the item design and the clarity of meaning. The second step was a pretest of the questionnaire. By purposive sampling, this study conducted sampling on franchise stores in Tainan City. A total of 80 samples were acquired. The questionnaires were completed by a self-administered survey. Via statistical methods, this study then identified the items that should be eliminated.

The data analysis of the pretest was based on a factor analysis and on Cronbach's $\alpha$. In the factor analysis, an eigenvalue of more than 1.00 was the standard for extracting the factors, and varimax rotation was used. Based on the statistical results, inferior items were eliminated. This study deleted the item if its elimination can improve Cronbach's $\alpha$ or it had a factor loading of less than 0.6 . The resulting revised questionnaire then became the formal survey tool.

\subsection{Sample}

We next conducted the formal research. The sample population was franchise stores with franchising contracts in franchise systems in Taiwan. Because the owners or managers of franchise stores usually handle interactions between franchise stores and franchisers, general employees are usually less aware of the status of the relationship. Thus, this study limited the 
respondents of the questionnaire to the owners or managers of franchise stores. By purposive sampling and interviews with personnel, we collected 600 questionnaires. After eliminating responses with incomplete or random answers, this study acquired 550 valid questionnaires.

The samples of this study were drawn from various general industries, including watch and clock stores $(7.3 \%)$, convenience stores $(9.3 \%)$, Chinese food restaurants $(4.5 \%)$, western food restaurants $(5.3 \%)$, clothing stores $(4.0 \%)$, computer stores $(12.4 \%)$, communication outlets $(11.5 \%)$, bookstores $(5.1 \%)$, extension classes $(4.2 \%)$, beauty and hair salons $(4.5 \%)$, eyeglasses stores $(8.7 \%)$, photo developing and printing stores $(11.5 \%)$, real estate agents $(8.2 \%)$, and others $(3.5 \%)$. The samples were located in urban areas of northern $(41.1 \%)$, central $(26.5 \%)$, and southern Taiwan (32.4\%). Of the participants, $47.3 \%$ were male and $52.7 \%$ were female. For the age of the franchise stores, 1-3 years was the most common age (27.6\%), followed by $3-5$ years $(19.8 \%)$.

\subsection{Common method variance}

There are five constructs in this study, two variables for relationship context (idiosyncratic investment and interdependence) and three variables for relationship quality (opportunistic behavior, trust and commitment). Measurement of the constructs was based on the same 7-point Likert scale. Each participant filled in all items of the questionnaire. This process could result in the problem of common method variance (CMV). Thus, this study adopted measures (avoidance of worry, mixture of items, improvement of item meanings, hiding of construct names and the design of reverse items) to avoid the problem of common method variance (Podsakoff, MacKenzie, Lee, and Podsakoff, 2003). Before testing the model, we used the most common method, Harman's single-factor test, to test whether common method variance was a problem. Podsakoff, MacKenzie, Lee, and Podsakoff (2003) suggested conducting exploratory factor analysis on items and analyzing the results of factor analysis without rotation. They indicated that the conditions indicating serious common method variance were (1) when only one factor is acquired by factor analysis and (2) when a general factor can explain most of the common variance in the measurement. We conducted exploratory non-rotated factor analysis on items for all variables and extracted five factors with an eigenvalue greater than 1 (thus rejecting condition 1). One general factor explained $33.83 \%$ of the variance and could not explain most of the common variance (thus rejecting condition 2). Hence, the two serious conditions of common method variance did not exist in this study.

Next, we conducted a confirmatory factor analysis to determine whether all items were from a single factor. This study found that the model fit for a single factor was not good. The fit measures of the model did not match the threshold values of the model fit (chi-square $=18091$, the degree of freedom $=4185, \mathrm{p}$ value below 0.001 ). The RMR (root mean squared residual) was 0.25 and above 0.05 (Byrne, 2001), the GFI (goodness of fit index) was 0.46 and below 0.9 (Hu and Bentler, 1999), the AGFI (adjusted goodness of fit index) was 0.44 and below 0.9 (Hu and Bentler, 1999), the CFI (comparative fit index) was 0.61 and below 0.95 (Hu and Bentler, 1999), and the RMSEA (root mean squared error of approximation) was 0.11 and above 0.08 (Browne and Cudeck, 1992). Thus, the assumption that all items were from single factor was not supported. Based on the results of the above two methods, common method variance is not 
a significant problem for this study.

\section{Research Results}

A reliability analysis was conducted on each construct to eliminate items whose removal significantly enhanced Cronbach's $\alpha$. We then conducted exploratory factor analysis on each construct and deleted items with factor loadings of less than 0.6. Reliability tests and exploratory factor analyses were conducted again on the remaining items. The results are shown in Tables 1 and 2.

To measure interdependence, we used the combination of franchisees' dependence on franchisers and franchisers' dependence on franchisees (three items for each) which were a composite index. Because dependence is a composite, it is not meaningful to discuss the reliability and validity for dependence and interdependence construct. For the other constructs, idiosyncratic investment had the lowest Cronbach's $\alpha$ (0.78), while trust had the highest (0.93). All constructs exceeded the standard of 0.7 (Table 1), indicating that they all had good reliability (Nunnally, 1978).

This study analyzed convergent validity and discriminant validity. First, we conducted exploratory factor analysis for each construct to extract common factors with an eigenvalue greater than 1 . The factor loadings all exceeded 0.6 and the percentages of the variance extracted for each construct was above $60 \%$ (Table 1). Thus, in this study, all constructs had good convergent validity. For discriminant validity, Gaski and Nevin (1985) suggested that when the correlation coefficient between two constructs is lower than the individual Cronbach's $\alpha$, the two constructs have good discriminant validity. Based on the results shown in Table 2, the correlation coefficients of all paired constructs in this study were lower than the individual Cronbach's $\alpha$ of the paired constructs. Thus, the constructs of this study had good discriminant validity.

The measurements of the constructs in this study were significantly related to each other $(p<0.01)$. Thus, it was necessary to clarify the causal relationship of these constructs. The correlation coefficients are shown in Table 2. 
Table 1. Items and the result of the factor analysis

\begin{tabular}{llcc}
\hline Constructs and items & $\begin{array}{l}\text { Factor } \\
\text { loading }\end{array}$ & AVE & $\begin{array}{l}\text { Cronbach's } \\
\text { alpha }\end{array}$ \\
\hline Idiosyncratic investment & & $69.92 \%$ & 0.78
\end{tabular}

If we switched to another franchise relationship, we would

0.86

forfeit much of the investment we have made in this franchiser.

It would be difficult for us to recoup investments made in this franchiser if we switched to another franchise relationship.

If we decided to stop the current franchising relationship, we would have significant trouble redeploying our people and facilities.

We have given extensive training to our customers on how to use this franchiser's product.

We have gone out of our way to align ourselves with this franchiser in the customer's mind.

We have invested a great deal to build up this franchiser's business.

We have made a substantial investment in facilities dedicated to this franchiser.

We have made a substantial investment to create a reporting system that is similar to this franchiser's.

Because we cooperate well with the franchiser, we obtain significant advantages.

0.66

0.78

0.74

\section{Franchisers' dependence on franchisees}

Franchisers can easily find franchisees for cooperation.

If the franchisers replace us with other franchisees, the franchisers will encounter little cost.

It is difficult for franchisers to find other franchisees to replace our sales and profits.

\section{Franchisees' dependence on franchisers}

There are other franchisers who produce products that are similar to this franchiser's.

To switch franchise systems, we must pay a very high cost. If we participate in other franchise systems, it will be difficult to obtain our current profits and sales. 
Sometimes we must hide the truth to acquire what we need.

0.78

Sometimes we do not accomplish what we have promised

0.76 to the franchiser.

It is not good to be totally honest with the franchiser.

We only report the positive side to the franchiser.

0.72

Sometimes we must lie to the franchiser to protect our benefits.

We think that the franchiser is not totally honest with us; thus, we are not totally honest with him/her.

Sometimes we must exaggerate what we need to acquire it.

0.80

Trust

$68.23 \%$

0.93

We believe that what the franchiser has said is the truth.

0.79

The franchiser will fulfill promises to us.

0.79

The franchiser's suggestions for our operations are sincere. $\quad 0.79$

We believe that the franchiser is honest.

0.86

Although the environment is different, we believe that the

0.87 franchiser is prepared and willing to help and support us.

When the franchiser makes significant decisions, he/she will consider our benefits.

When we show our problems to the franchiser, he/she has a friendly response.

We believe that the franchiser will be concerned about the effects of his/her decision making and actions on us.

\section{Affective commitment}

$68.72 \%$

0.91

We are willing to work on the future with the franchiser.

0.84

We feel that the problems in the franchise system are ours. $\quad 0.73$

We do not have a strong intention to belong to this franchise $\quad 0.78$ system.

We do not have affective attachment to this franchise 0.85 system.

We do not want to be part of this franchise system.

This franchise system is meaningful to us.

0.88 
Table 2. Mean, standard deviation and discriminant validity of constructs

\begin{tabular}{|c|c|c|c|c|c|c|c|}
\hline $\begin{array}{c}\text { Constructs } \\
\text { (number of items) }\end{array}$ & Mean & $\begin{array}{l}\text { Standard } \\
\text { deviation }\end{array}$ & 1 & 2 & 3 & 4 & 5 \\
\hline $\begin{array}{l}\text { 1.Idiosyncratic } \\
\text { investment (9) }\end{array}$ & 4.70 & 1.03 & $(0.78)$ & & & & \\
\hline 2.Interdependence (6) & 3.86 & 0.83 & 0.19 & -- & & & \\
\hline $\begin{array}{l}\text { 3.Opportunistic } \\
\text { behavior (7) }\end{array}$ & 2.97 & 1.39 & -0.19 & -0.29 & $(0.89)$ & & \\
\hline 4.Trust (8) & 4.77 & 1.37 & 0.33 & 0.28 & -0.45 & $(0.93)$ & \\
\hline 5.Commitment (6) & 5.02 & 1.42 & 0.41 & 0.25 & -0.45 & 0.73 & $(0.91)$ \\
\hline
\end{tabular}

Note: ( ) is Cronbach's $\alpha$; the remaining are correlation coefficients, all of which reached a significance level of $\mathrm{p}<0.01$.

We next conducted a structural equation modeling (SEM) analysis of the relationships of the observable variables shown in the research framework (Figure 1) using LISREL 8.72 to examine the model's fit with the data and to validate the hypotheses.

For the model fit, SRMR=0.04 $(<0.05), \mathrm{GFI}=0.98, \mathrm{NFI}=0.96, \mathrm{CFI}=0.96$, and $\mathrm{IFI}=0.96(>0.9)$. All results were better than the threshold values in the literature (Bagozzi and Yi, 1988; Joreskog and Sorbom, 1989). Thus, the model fit of this study was good.

Squared multiple correlations (SMC) were used to judge the explanatory power of the model for the dependent variables. The research findings indicated that, except for interdependence (4\%), the explanatory power of the model for the rest of the dependent variables was good: for opportunistic behavior it was $23 \%$, for trust $16 \%$, and for commitment $56 \%$.

To validate the hypotheses, the maximum likelihood estimates of the path coefficients are shown in Table 3. The positive and negative symbols of the standardized path coefficients (or $t$ value) and the absolute value of the $t$ value $>1.96(p<0.05)$ were used to judge the results of the hypotheses validation. As the last column of Table 3 shows, among the eight hypotheses, seven were supported by this study. However, H2 (idiosyncratic investment negatively influences opportunistic behavior) was not supported. Although the empirical result of $\mathrm{H} 2$ was insignificant, the direction was the same as the hypothesis. 
Table 3. Analytical results of the SEM

\begin{tabular}{|c|c|c|c|c|}
\hline Hypothesis & Description & $\begin{array}{c}\text { Standardized } \\
\text { path coefficient }\end{array}$ & t value & $\begin{array}{l}\text { Result of } \\
\text { hypothesis } \\
\text { validation }\end{array}$ \\
\hline $\mathrm{H} 1$ & $\begin{array}{l}\text { Idiosyncratic investment positively } \\
\text { influences interdependence }\end{array}$ & $0.19 * * *$ & 4.62 & Supported \\
\hline $\mathrm{H} 2$ & $\begin{array}{l}\text { Idiosyncratic investment negatively } \\
\text { influences opportunistic behavior }\end{array}$ & -0.02 & -0.52 & Not supported \\
\hline $\mathrm{H} 3$ & $\begin{array}{l}\text { Idiosyncratic investment positively } \\
\text { influences trust }\end{array}$ & $0.29 * * *$ & 7.27 & Supported \\
\hline $\mathrm{H} 4$ & $\begin{array}{l}\text { Interdependence negatively influences } \\
\text { opportunistic behavior }\end{array}$ & $-0.17 * * *$ & -4.37 & Supported \\
\hline H5 & $\begin{array}{l}\text { Interdependence positively influences } \\
\text { trust }\end{array}$ & $0.22 * * *$ & 5.55 & Supported \\
\hline H6 & $\begin{array}{l}\text { Trust negatively } \quad \text { influences } \\
\text { opportunistic behavior }\end{array}$ & $-0.39 * * *$ & -9.62 & Supported \\
\hline $\mathrm{H} 7$ & $\begin{array}{l}\text { Opportunistic behavior } \\
\text { influences commitment }\end{array}$ & $-0.15 * * *$ & -4.60 & Supported \\
\hline $\mathrm{H} 8$ & $\begin{array}{l}\text { Trust positively } \\
\text { commitment }\end{array}$ & $0.67 * * *$ & 21.03 & Supported \\
\hline
\end{tabular}

$* * * \mathrm{p}<0.001$

\section{Summary}

This study has theoretical and practical contributions. Through integrating previous research on relationship quality, this study clarified the relationship among the three variables (opportunistic behavior, trust, and commitment) of relationship quality. In addition, it clarified the relationship between the relationship context and the variables of relationship quality, and it recognized a path for producing franchisee commitment. On the practical side, the findings of this study enable franchisers to understand the relationship contexts that enhance relationship quality with franchisees.

This study constructed a model of the relationship context and relationship quality and validated the overall model fit and relationships among the variables using structural equation modeling. According to the findings, the model had an acceptable goodness of fit. The empirical results of this study are shown in Figure 2, which clearly indicates the causal relationships among variables, particularly the mediating effects. 


\section{Macrothink}

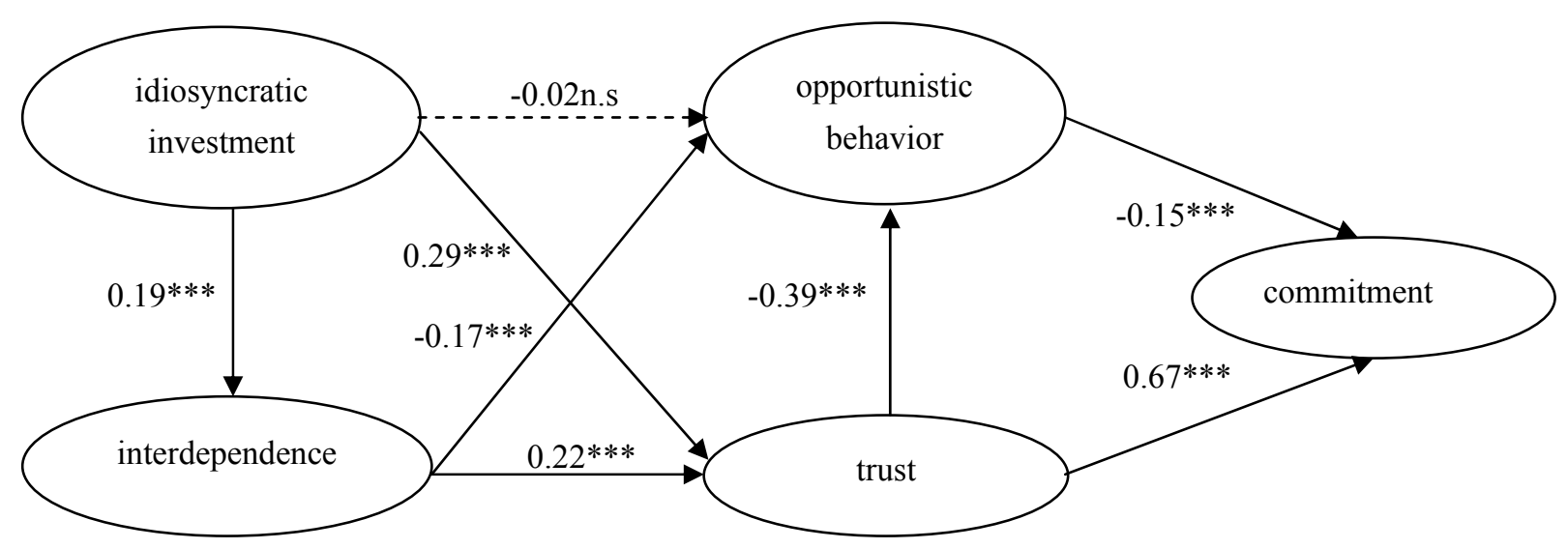

Figure 2. Empirical results

Note: The dotted line means the empirical results did not support the hypothesis. The solid line means the empirical results supported the hypothesis.

*** $\mathrm{p}<0.001 ;$ n.s denotes non-significant

According to the findings of this study, franchise relationship quality will be enhanced by the relationship context of idiosyncratic investment and interdependence. Idiosyncratic investment is the antecedent of interdependence. Idiosyncratic investment directly enhances trust and indirectly reinforces trust via interdependence. Franchisee idiosyncratic investment cannot directly lower opportunistic behavior and must instead rely on the pathways of trust or interdependence. In addition, franchisees with less opportunistic behavior have higher commitment. Franchisees who trust franchisers have higher commitment. Moreover, trust also results in commitment via the reduction of opportunistic behavior.

\section{Discussion}

Hypothesis H2 (idiosyncratic investment negatively influences opportunistic behavior) was not empirically supported by this study. The subjects of this study were franchise stores with franchising contracts in the chain franchise systems of Taiwan. First, franchisees are in a vertically integrated channel structure and are controlled by franchising contracts. Hence, opportunistic behavior is restricted. Therefore, the effect of idiosyncratic investment on opportunistic behavior is lower. Second, the franchisees in this study were small and medium enterprises whose idiosyncratic investments were not significantly different. Low discreteness of the variable data may reduce the significance of the causal relationships. Third, because the operating scale of the franchisees in this study was not large, the idiosyncratic investment was low, leading to negligible "lock-in" effects. Brown, Dev, and Lee (2000) studied hotel franchise industry in which idiosyncratic investment has a larger scale than our study. The scale of idiosyncratic investment may cause the different finding that whether idiosyncratic investment directly influences opportunistic behavior. Fourth, the idiosyncratic investment in this study was merely the franchisee investment. Before producing interdependence, 
idiosyncratic investment cannot effectively prevent franchisee opportunistic behavior. This result was an important theoretical finding of this study. Lui, Wong, and Liu (2009) explored the channel relationship of market governance and demonstrated that idiosyncratic investment in partnerships can enhance trust among partners, leading to greater cooperation and better partnership performance. Similar to this study, Lui et al. found that the effect of idiosyncratic investment on opportunistic behavior was less significant.

\section{Future Research}

Idiosyncratic investment and interdependence can be divided into economic and social dimensions. Thus, it is suggested that future researchers explore the effects of the economic and social dimensions of idiosyncratic investment and interdependence on opportunistic behavior, trust, and commitment.

Jap and Anderson (2007) conducted a dynamic study on relationship variables and suggested that at different phases of the relationship life cycle (exploration, expansion, maturity, and declination/collapse), the degree of the relationship variables will be different, including some variables in this study (interdependence, idiosyncratic investment, and trust). Thus, future researchers should determine the degree of influence from the relationship variables at different phases of the relationship life cycle. Namely, whether the model developed herein is feasible across different phases of the relationship life cycle.

This study treats idiosyncratic investment as a relationship context variable in determining its effect on relationship quality. Our findings indicate that idiosyncratic investment will influence opportunistic behavior and trust via the mediation of interdependence. However, with higher relationship quality, do franchisees have a greater intention to make idiosyncratic investments? The reverse causal relationship between idiosyncratic investment and relationship quality could be further clarified by a longitudinal study.

\section{Practical Implications}

The findings of this study suggest that franchisers should promote idiosyncratic investment and interdependence. Although this study did not provide specific methods, it does remind franchisers that relationship quality can be enhanced through two relationship contexts of idiosyncratic investment and interdependence.

Franchise systems are based on hierarchical governance, which provides stronger control than market governance. Franchisers should use their control advantage to induce franchisees to invest in training, facilities, and building a consistent customer image for the franchise, and then to strengthen their interdependence with franchisees, prevent franchisee opportunistic behavior, and increase franchisee trust.

\section{Acknowledgement}

The author is grateful to National Science Council in Taiwan for the financial support (NSC 99-2410-H-024-009) 


\section{References}

Andaleeb, S. S. (1992). The trust concept: Research issues for channels of distribution. Research in Marketing, 11, 1-34.

Andaleeb, S. S. (1996). An experimental investigation of satisfaction and commitment in marketing channels: The role of trust and dependence. Journal of Retailing, 72(1), 77-93. http://dx.doi.org/10.1016/S0022-4359(96)90006-8

Anderson, E., \& Weitz, B. (1992). The use of pledges to build and sustain commitment in distribution channels. Journal of Marketing Research, 29(1), 18-34. http://dx.doi.org/10.2307/3172490

Arrow, K. J. (1974). The limits of organization. New York: W.W. Norton.

Bacharach, S. B., \& Lawler, E. J. (1981). Bargaining: Power, tactics, and outcome. San Francisco: Jossey Bass.

Bagozzi, R. P., \& Yi, Y. (1988). On the evaluation of structural equation models. Journal of the Academy of Marketing Science, 16(1), 74-94. http://dx.doi.org/10.1007/BF02723327

Barber, B. (1983). The logical and limits of trust. New Brunswick, NJ: Rutgers University Press.

Bowen, J. T., \& Shoemaker, S. (1998). Loyalty: A strategic commitment. Cornell Hotel and Restaurant Administration Quarterly, 39(1), 12-25. http://dx.doi.org/10.1177/001088049803900104

Brown, J. R., Dev, C. S., \& Lee, D.-J. (2000). Managing marketing channel opportunism: The efficacy of alternative governance mechanisms. Journal of Marketing, 64(2), 51-65. http://dx.doi.org/10.1509/jmkg.64.2.51.17995

Browne, M. W., \& Cudeck, R. (1992). Alternative ways of assessing model fit. Sociological Methods and Research, 21(2), 230-258. http://dx.doi.org/10.1177/0049124192021002005

Buchanan, L. (1992). Vertical trade relationships: The role of dependence and symmetry in attaining organizational goals. Journal of Marketing Research, 29(1), 65-75. http://dx.doi.org/10.2307/3172493

Byrne, B. M. (2001). Structural equation modeling with AMOS: Basic concepts, applications, and programming. NJ: Lawrence Erlbaum Associates.

Churchill, G. A. (1979). A paradigm for developing better measures of marketing constructs. Journal of Marketing Research, 16(1), 64-73. http://dx.doi.org/10.2307/3150876

Dertouzos, M. L., Lester, R. K., \& Solow, R. M. (1989). Made in America: Regaining the productive edge. Cambridge, MA: The MIT Press.

Dwyer, F. R., Schurr, P. H., \& Oh, S. (1987). Developing buyer-seller relationships. Journal of Marketing, 51(2), 11-27. http://dx.doi.org/10.2307/1251126 
Edison, S., Hunt, S. D., \& Madhavaram, S. (2007). Inducing salespeople to sell proprietary products: Do transaction cost factors hinder? Do relational factors help? The Marketing Management Journal, 17(1), 1-14.

Elango, B., \& Fried, V. H. (1997). Franchising research: A literature review and synthesis. Journal of Small Business Management, 35(3), 68-81.

Erramilli, M. K., \& Rao, C. P. (1993). Service firms' international entry-mode choice: A modified transaction-cost analysis approach. Journal of Marketing, 57(3), 19-38. http://dx.doi.org/10.2307/1251852

Fairfield, K. D., \& Wagner, R. F. (2004). Whose side are you on? Interdependence and its consequences in management of healthcare delivery. Journal of Healthcare Management, 49(1), 17-29.

Frazier, G. L., \& Rody, R. C. (1991). The use of influence strategies in interfirm relationships in industrial product channels. Journal of Marketing, 55(1), 52-69. http://dx.doi.org/10.2307/1252203

Garbarino, E., \& Johnson, M. S. (1999). The different roles of satisfaction, trust, and commitment in customer relationships. Journal of Marketing, 63(2), 70-87. http://dx.doi.org/10.2307/1251946

Gaski, J. F., \& Nevin, J. R. (1985). The differential effects of exercised and unexercised power sources in a marketing channel. Journal of Marketing Research, 22(2), 130-142. http://dx.doi.org/10.2307/3151359

Goodman, L. E., \& Dion, P. A. (2001). The determinants of commitment in the distributor-manufacturer relationship. Industrial Marketing Management, 30(3), 287-300. http://dx.doi.org/10.1016/S0019-8501(99)00092-9

Gruen, T. W., Summers, J. O., \& Acito, F. (2000). Relationship marketing activities, commitment, and membership behaviors in professional associations. Journal of Marketing, 64(3), 34-49. http://dx.doi.org/10.1509/jmkg.64.3.34.18030

Gundlach, G. T., Achrol, R. S., \& Mentzer, J. T. (1995). The structure of commitment in exchange. Journal of Marketing, 59(1), 78-92. http://dx.doi.org/10.2307/1252016

Heide, J. B. (1994). Interorganizational governance in marketing channels. Journal of Marketing, 58(1), 71-85. http://dx.doi.org/10.2307/1252252

Heide, J. B., \& John, G. (1988). The role of dependence balancing in safeguarding transaction-specific assets in conventional channels. Journal of Marketing, 52(1), 20-35. http://dx.doi.org/10.2307/1251683

Hu, L., \& Bentler, P. M. (1999). Cutcoff criteria for fit indexes in covariance structure analysis: Conventional criteria versus new alternatives. Structural Equation Modeling, 6(1), 1-55. http://dx.doi.org/10.1080/10705519909540118

Jap, S. D. (1999). Pie-expansion efforts: Collaboration processes in buyer-supplier 
relationships. Journal of Marketing Research, 36(4), 461-475. http://dx.doi.org/10.2307/3152000

Jap, S. D., \& Anderson, E. (2007). Testing a life-cycle theory of cooperative interorganizational relationships: Movement across stages and performance. Management Science, 53(2), 260-275. http://dx.doi.org/10.1287/mnsc.1060.0610

Joreskog, K. G., \& Sorbom, D. (1989). LISREL®7: A guide to the program and application. Chicago, IL: Joreskog and Sorbom/SPSS Inc.

Joshi, A. W., \& Stump, R. L. (1999). Determinants of commitment and opportunism: Integrating and extending insights from transaction cost analysis and relational exchange theory. Canadian Journal of Administrative Sciences, 16(4), 334-352. http://dx.doi.org/10.1111/j.1936-4490.1999.tb00693.x

Kale, P., Singh, H., \& Perlmutter, H. (2000). Learning and protection of proprietary assets in strategic alliances: Building relational capital. Strategic Management Journal, 21(3), 217-237. http://dx.doi.org/10.1002/(SICI)1097-0266(200003)21:3\%3C217::AID-SMJ95\%3E3.3.CO;2$\mathrm{P}$

Kumar, N., Scheer, L. K., \& Steenkamp, J.-B. E. M. (1995a). The effects of supplier fairness on vulnerable resellers. Journal of Marketing Research, 32(1), 54-65. http://dx.doi.org/10.2307/3152110

Kumar, N., Scheer, L. K., \& Steenkamp, J.-B. E. M. (1995b). The effects of perceived interdependence on dealer attitudes. Journal of Marketing Research, 32(3), 348-356. http://dx.doi.org/10.2307/3151986

Larson, A. (1992). Network dyads in entrepreneurial settings: A study of the governance of exchange relationships. Administrative Science Quarterly, 37(1), 76-104. http://dx.doi.org/10.2307/2393534

Lui, S. S., \& Ngo, H.-Y. (2005). An action pattern model of inter-firm cooperation. Journal of Management Studies, 42(6), 1123-1153. http://dx.doi.org/10.1111/j.1467-6486.2005.00536.x

Lui, S. S., Wong, Y. Y., \& Liu, W. P. (2009). Asset specificity roles in interfirm cooperation: Reducing opportunistic behavior or increasing cooperative behavior? Journal of Business Research, 62(11), 1214-1219. http://dx.doi.org/10.1016/j.jbusres.2008.08.003

MacNeil, I. R. (1980). The new social contract, an inquiry into modern contractual relations. New Haven, CT: Yale University Press.

McDonald, G. W. (1981). Structural exchange and marital interaction. Journal of Marriage and Family, 43(4), 825-839. http://dx.doi.org/10.2307/351340

Meyer, J. P., Allen, N. J., \& Smith, C. A. (1993). Commitment to organizations and occupations: Extension and test of a three-component conceptualization. Journal of Applied Psychology, 78(4), 538-551. http://dx.doi.org/10.1037//0021-9010.78.4.538

Moore, K. R. (1998). Trust and relationship commitment in logistics alliances: A buyer 
perspective. International Journal of Purchasing and Materials Management, 34(4), 24-37. http://dx.doi.org/10.1111/j.1745-493X.1998.tb00039.x

Moorman, C., Zaltman, G., \& Deshpande, R. (1992). Relationships between providers and users of market research: The dynamics of trust within and between organizations. Journal of Marketing Research, 29(3), 314-328. http://dx.doi.org/10.2307/3172742

Morgan, R. M., \& Hunt, S. D. (1994). The commitment-trust theory of relationship marketing. Journal of Marketing, 58(3), 20-38. http://dx.doi.org/10.2307/1252308

Nunnally, J. C. (1978). Psychometric theory (2nd ed.). New York: McGraw-Hill Book Company.

Palmatier, R. W., Dant, R. P., \& Grewal, D. (2007). A comparative longitudinal analysis of theoretical perspectives of interorganizational relationship performance. Journal of Marketing, 71(4), 172-194. http://dx.doi.org/10.1509/jmkg.71.4.172

Podsakoff, P. M., MacKenzie, S. B., Lee, J.-Y., \& Podsakoff, N. P. (2003). Common method biases in behavioral research: A critical review of the literature and recommended remedies. $\begin{array}{lllr}\text { Journal of } & \text { Applied } & \text { Psychology, } & 88(5),\end{array}$ http://dx.doi.org/10.1037/0021-9010.88.5.879

Porter, L. W., Steers, R. M., Mowday, R. T., \& Boulian, P. V. (1974). Organizational commitment, job satisfaction, and turnover among psychiatric technicians. Journal of Applied Psychology, 59(5), 603-609. http://dx.doi.org/10.1037/h0037335

Provan, K. G., \& Skinner, S. J. (1989). Interorganizational dependence and control as predictors of opportunism in dealer-supplier relations. Academy of Management Journal, 32(1), 202-212. http://dx.doi.org/10.2307/256427

Ramaswami, S. N., \& Singh, J. (2003). Antecedents and consequences of merit pay fairness for industrial salespeople. Journal of Marketing, 67(4), 46-66. http://dx.doi.org/10.1509/jmkg.67.4.46.18690

Ring, P. S., \& Van de Ven, A. H. (1992). Structuring cooperative relationships between organizations. Strategic Management Journal, 13(7), 483-498. http://dx.doi.org/10.1002/smj.4250130702

Ring, P. S., \& Van de Ven, A. H. (1994). Developmental processes of cooperative interorganizational relationships. Academy of Management Review, 19(1), 90-118. http://dx.doi.org/10.2307/258836

Sarkar, M., Aulakh, P. S., \& Cavusgil, S. T. (1998). The strategic role of relational bonding in interorganizational collaborations: An empirical study of the global construction industry. Journal of International Management, 4(2), 85-107. http://dx.doi.org/10.1016/S1075-4253(98)00009-X

Shockley-Zalabak, P., Ellis, K., \& Winograd, G. (2000). Organizational trust: What it means, why it matters. Organization Development Journal, 18(4), 35-48. 


\section{Macrothink}

Journal of Management Research

ISSN 1941-899X 2014, Vol. 6, No. 3

Skarmeas, D., \& Robson, M. J. (2008). Determinants of relationship quality in importer-exporter relationships. British Journal of Management, 19(2), 171-184. http://dx.doi.org/10.1111/j.1467-8551.2007.00537.x

Smith, J. B., \& Barclay, D. W. (1999). Selling partner relationships: The role of interdependence and relative influence. Journal of Personal Selling and Sales Management, 19(4), 21-40.

Tan, H. H., \& Tan, C. S. F. (2000). Toward the differentiation of trust in supervisor and trust in organization. Genetic, Social, and General Psychology Monographs, 126(2), 241-260.

Ting, S.-C., Chen, C.-N., \& Bartholomew, D. E. (2007). An integrated study of entrepreneurs' opportunism. Journal of Business and Industrial Marketing, 22(5), 322-335. http://dx.doi.org/10.1108/08858620710773459

Tjosvold, D., \& Weicker, D. (1993). Cooperative and competitive networking by entrepreneurs: A critical incident study. Journal of Small Business Management, 31(1), 11-21.

Whyte Jr., W. H. (1956). The organization man. New York: Simon and Schuster.

Williamson, O. E. (1975). Markets and hierarchies: Analysis and antitrust implications. New York: The Free Press.

Williamson, O. E. (1985). The economic institutions of capitalism. New York: The Free Press. 